American Journal of Environmental Sciences 8 (1): 56-63, 2012

ISSN 1553-345X

(C) 2012 Science Publications

\title{
Characterization, Concentrations and Emission Rates of Volatile Organic Compounds from Two Major Landfill Sites in Kuwait
}

\author{
${ }^{1,2}$ Mohammad AlAhmad, ${ }^{2}$ Marwan Dimashki, ${ }^{1}$ Abdallah Nassour and ${ }^{1}$ Michael Nelles \\ ${ }^{1}$ Department of Waste Management, Institute of Environmental Engineering, \\ Faculty of Agricultural and Environmental Sciences, 18051 Rostock, Germany \\ ${ }^{2}$ Environmental Monitoring Information System of Kuwait (eMISK), \\ Environment Public Authority, 24395-AlSafat, 13104, Kuwait
}

\begin{abstract}
Problem statement: The emission of pollutants from landfill sites in Kuwait is of major concern due to the associated adverse environmental and health impacts. There are 18 landfill sites in Kuwait which are contributing to the emission of atmospheric pollutants including; methane, carbon dioxide and Volatile Organic Compounds (VOCs). Approach: Determine the concentration and composition of VOCs in LFG emissions from two major landfill sites in Kuwait and to investigate the influence of the "In-Situ Aerobic Stabilization" on the reduction of VOCs emission. VOCs samples were collected during an intensive, short-term field sampling campaign conducted in 2010 where 50 individual volatile organic compounds were identified and quantified in landfill gas samples collected from the two landfill sites and the Project Area. Results: The concentration levels of VOCs were found to be significantly different within the same landfill site; however, the average total VOCs emissions were comparable between the two landfill sites. Concentration of total VOCs (i.e., sum of 50 compounds) in LFG emissions varied between 9.4-67.2 ppm in Jleeb Al-Shuyoukh landfill site and from 15.4-57.7 ppm in Al-Qurain landfill site. Annual emissions of the well-known five VOCs (i.e., benzene, toluene, ethylbenzene, m-, o- and p-xylenes and styrene) were also computed for each vent pipe from Jleeb Al-Shuyoukh landfill using the measured average concentrations and LFG flow rates. The results, if calculated in terms of the average $\Sigma B T E X+S$ quantity emitted per vent pipe per year, showed that the magnitude of $\Sigma B T E X+S$ emissions ranged between $0.108-11.686 \mathrm{~g} \mathrm{y}^{-1}$. Conclusion: The results of this pilot project demonstrated that the "insitu aerobic stabilization method" applied on old solid waste deposits in the project area of Jleeb AlShuyoukh landfill can significantly reduce the average VOCs concentration in LFG emissions from high-productivity wells in the project area down to $(6.3 \pm 1.6 \mathrm{ppm})$, whereas VOCs concentration in LFG emissions from high-productivity wells in Jleeb Al-Shuyoukh landfill and Al-Qurain landfill sites remained relatively high, $57.1 \pm 6.95$ and $49.8 \pm 11.2 \mathrm{ppm}$, respectively.
\end{abstract}

Key words: VOCs, NMOCs, BTEX, Municipal Solid Waste, Landfills, LFG, emissions

\section{INTRODUCTION}

After placement of Municipal Solid Wastes (MSW) in landfills; many biological, chemical and physical processes start to take place which would gradually lead to the emission of Landfill Gas (LFG) to air and leachates through ground (Awomeso et al., 2010; Williams, 2005). A significant fraction of the biodegradable portion of MSW is ultimately converted to gaseous end-products during the anaerobic stabilization of solid waste organic fractions (Abushammala et al., 2009). Usually, gas production begins within a year of waste placement and may continue for as long as 50 years after landfill closure. Landfill Gas (LFG) consists usually of $50-60 \% \mathrm{CH}_{4}$, 30-40 vol. $\% \mathrm{CO}_{2}$ and other trace gases (Wang-Yao et al., 2006). Non-Methane Organic Compounds (NMOCs) usually make up also less than $1 \%$ of landfill gas. Various trace gases such as hydrogen sulfide, water vapor, ammonia and a variety of volatile Organic Compounds (VOCs) are also present in LFG. European research has identified that landfill gas is composed of 140 trace components of which 90 were common to all studied landfill sites (Parker et al., 2002).

The emission of LFG is of major concern to local communities because of the bad smell and offensive

Corresponding Author: Mohammad AlAhmad, Department of Waste Management, Institute of Environmental Engineering, Faculty of Agricultural and Environmental Sciences, 18051 Rostock Germany 
odour as well as due to the various potential health hazards associated with toxic organic and inorganic compounds present in LFG. On the regional scale, LFG emissions are considered as a source of VOCs which contribute to the formation of photochemical oxidants including ground-level ozone $\left(\mathrm{O}_{3}\right)$. On the global scale, the emission of methane in LFG contributes to greenhouse effects. The waste sector is considered a significant contributor to Greenhouse Gas (GHG) emissions accountable for approximately 5\% of the global greenhouse budget (IPCC, 2006). Atmospheric methane gas $\left(\mathrm{CH}_{4}\right)$ has more than doubled in concentration over the last 150 years (Stern et al., 2007).

Numerous investigations have been conducted with the objective of characterizing landfill gas emissions. More than fifty different VOCs have been identified in landfill gases (Kim et al., 2006). The list includes simple alkanes, olefins, aromatics and a wide array of chlorinated compounds. These VOCs include a number of known or suspected carcinogens (such as benzene, styrene and vinyl chloride). The concentrations of VOCs found in LFG typically range from a few parts per billion $(\mathrm{ppb})$ to tens of thousands of $\mathrm{ppb}$. Benzene, Toluene, Ethyl Benzene and Xylene (BTEX) compounds as well as methylated-and alkylated benzenes are frequently observed as trace contaminants in landfill gas.

The primary objective of the current study was to characterize VOCs emissions in LFG and to compare the composition and emission rates of VOCs between two major landfill sites in the State of Kuwait. The study also investigated the influence of in-situ aerobic stabilization of old solid waste deposits on the composition and concentration of VOCs in LFG emission.

\section{MATERIALS AND METHODS}

Landfill sites: The most common practised disposal method in the State of Kuwait for Municipal Solid Waste (MSW) is burial in landfills (UNDP, 2002; AlAhmad et al., 2003). Today, there are 18 landfills in Kuwait of which 14 sites are closed and 4 sites are still in operation (AlAhmad, 2009). Detailed information and data about these landfills, their waste input and composition or emissions measurements and characterization of VOCs in LFG do not exist. Due to the rapid development and the expansion in urban and residential areas in Kuwait, some of these landfills became on the boarders of residential and urban areas, as is the case of Jleeb Al-Shuyoukh and Al-Qurain landfill sites (Fig. 1).

Jleeb Al-Shuyoukh landfill: The landfill of Jleeb AlShuyoukh is located in the south of Kuwait City close to the International Airport of Kuwait and adjacent to the south-eastern boarder of Abdullah Al-Mubarak residential area. This landfill site was licensed by
Kuwait Municipality to receive MSW from 1970-1993. The site is considered to be the largest MSW landfill in Kuwait where it encompasses approximately 6 square kilometres and the waste vertical profile varies in depth from 4-23 m. Approximately, about 20 million cubic meters of municipal solid waste and 3 million cubic meters of demolition waste were dumped during the operation period of the landfill. After a major burning incident of the landfill in 2002, a surface capping system with $1 \mathrm{~m}$-soil layer was installed. In 2006, 50 boreholes (depth up to $29 \mathrm{~m}$ ) were drilled for measurement of landfill gas emissions. Measurements of LFG emission was started in March 2008 by the Environment Public Authority of Kuwait (KEPA).

In November 2008, a small area of Jleeb AlShuyoukh $\left(576 \mathrm{~m}^{2}\right)$ was used to conduct this research project in collaboration with the Department of Waste Management at Rostock University in Germany. Aerobic in-situ stabilization of old solid waste deposits (Heyer et al., 2003; 2005; Cossu et al., 2006; Zanetti, 2008) was applied in the "Project Area" of Jleeb AlShuyoukh landfill to examine how this method would improve the emission behaviour and composition of landfill gas under the local conditions of Kuwait (AlAhamd, 2009). In-situ aerobic stabilization of MSW aims to achieve accelerated reduction of the emission and settlement potentials, reduction of the technical and financial expenditures during the aftercare phase and a reduction of the aftercare period. Extensive scientific research have shown that a sustained improvement of the emission and settlement behaviour of the landfill through aerobic in-situ stabilization measures can be achieved when the process technology is adapted to the local conditions of the landfill body and operated in a qualified manner (Spillmann et al., 2001; Heyer et al., 2003; 2005).

Al-Qurain landfill site: As shown in Fig. 1 above, this site has become over the past years entirely surrounded by residential areas from all sides due to the expansion of nearby residential areas. The area of Al-Qurain landfill was originally used for dumping of municipal and construction waste from 1970-1985. The volume of the landfill is approximately 5 million $\mathrm{m}^{3}$ and the maximum depth of waste is $24 \mathrm{~m}$. The surface is capped with a $1 \mathrm{~m}$ soil layer. The landfill is equipped with an active LFG venting and collection system, a flare for burning-off LFG and a pre-treatment plant for leachate. The gas venting system has been in operation since 2005 .

Sample collection: During the period May-August 2010, twenty eight samples were collected from selected monitoring wells (boreholes) in Jleeb landfill, the "Project Area" in Jleeb landfill and from Al-Qurain landfill site (Fig. 2 and 3 for the locations of boreholes used for sampling of VOCs). 


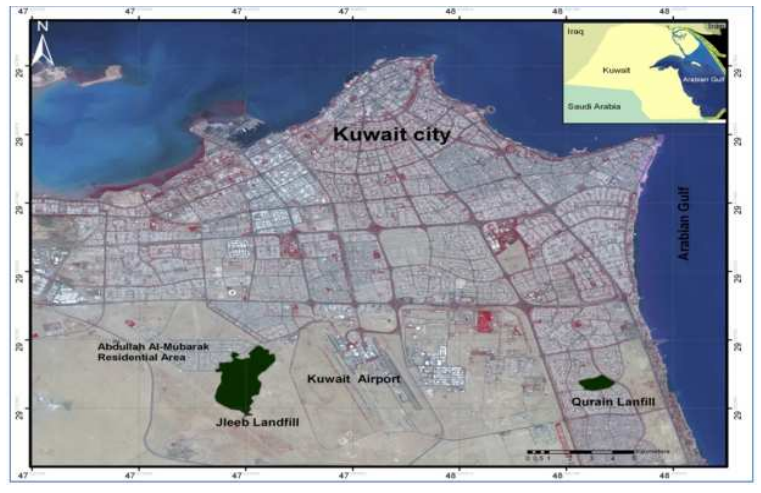

Fig. 1: Satellite image of Kuwait City (SPOT, April 2010) showing the location of the two landfill sites (areas coloured in dark green)

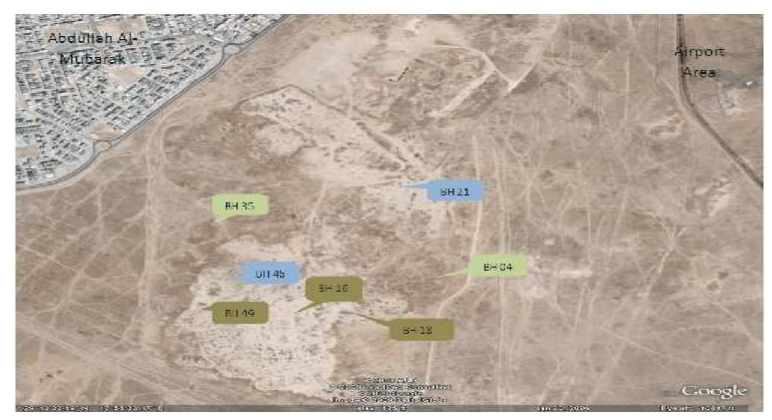

Fig. 2:Location of boreholes used for the collection of VOCs samples from Jleeb landfill site

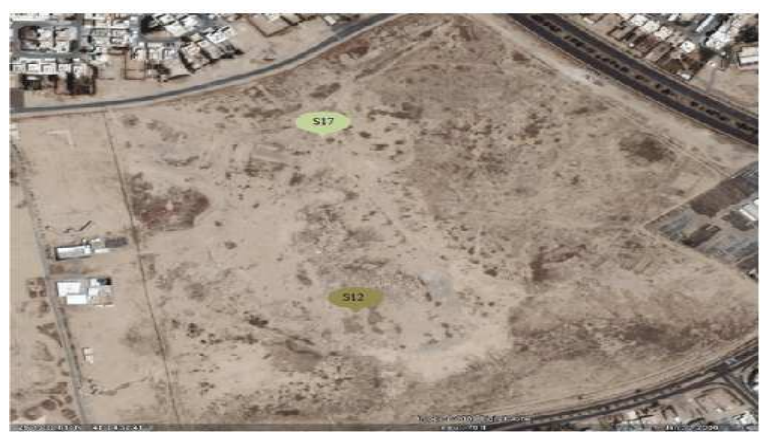

Fig. 3:Location of boreholes used for the collection of VOCs samples from Al-Qurain landfill

Table 1 gives short descriptions of the boreholes used for sampling. Boreholes 4 and 35 in Jleeb landfill were chosen to represent the native soils in the area with no waste buried underneath.

Boreholes 21 and 46 in Jleeb Al-Shuyoukh landfill and borehole S17 in Al-Qurain landfill were chosen to represent wells of low methane productivity, whereas boreholes 16 and 49 in Jleeb landfill and borehole S12 in Al-Qurain landfill were chosen to represent wells of high methane productivity (i.e., reaching a mature methanization stage). Borehole No 18 in Jleeb landfill was chosen following the aeration experiment (i.e., insitu aerobic stabilization of buried wastes) applied in the in the "Project Area".

Prior to the sampling of VOCs, the borehole valve was opened and connected to a hand-held portable device (GA 2000 Plus infrared gas analyser, Geotechnical Instruments-UK) for the in-situ measurement of $\mathrm{CH}_{4}$, $\mathrm{CO}_{2}, \mathrm{CO}, \mathrm{O}_{2}$ and temperature in LFG. Sampling of VOCs was achieved using a clean Tedlar bag $(1 \mathrm{~L})$ and a small vacuum pump.

Sample analysis: Collected samples were brought to the analytical laboratory for the analysis of Volatile Organic Compounds (VOCs) in landfill gas. Fifty individual VOCs were identified and quantified in this study, ranging from simple aliphatic and aromatic hydrocarbons to di-and tri-methylated benzenes. The target volatile organic compounds identified and quantified in this study are listed in Table 2.

Analysis of VOCs in the collected gas samples was accomplished by following USEPA Method PAMS (Photochemical Assessment Monitoring Stations). The analytical system included a gas chromatography system (Perkin Elmer) equipped with flame ionization detector (GC/FID). The Gas Chromatography system (GC) was also equipped with a perkin elmer Automatic Thermal Desorber (ATD 400). The VOC samples contained in Tedlar bags were analyzed by introducing them into the GC/FID system with the aid of Peltier Cooling (PC) and the Thermal Desorption (TD) method (PC/TD system). Using this PC/TD system, the target VOC in LFG samples were then pre-concentrated in a liquid $\mathrm{N}_{2}$-free cold trap (packed with both Carbosil adsorbent) at $-15^{\circ} \mathrm{C}$. Trapped VOC were then released thermally by heating the cold trap for $2 \mathrm{~min}$ at $320^{\circ} \mathrm{C}$.

A $30 \mathrm{~m} \mathrm{GC}$ capillary column (BP1) was used for the chromatographic separation of the different VOCs. After elution from the capillary column, identification of individual VOCs compounds was achieved by the Flame Ionization Detector (GC/FID) connected at the end of the capillary column.

Figure 4 and 5 show the GC/FID chromatograms recorded during the identification of light and heavy molecular weight VOCs in LFG samples, respectively. Appropriate calibration procedures were employed to ensure GC/FID reliability and accuracy. The GC/FID system was calibrated using a standard calibration cylinder (Spectra Gases, UK) containing all light and heavy molecular weight VOCs at a concentration of 100 ppb each. Detection limits for all VOCs was about $5 \mathrm{ppb}$. 
Am. J. Environ. Sci., 8 (1): 56-63, 2012

\begin{tabular}{|c|c|c|c|c|}
\hline $\begin{array}{l}\text { Landfill } \\
\text { site }\end{array}$ & $\begin{array}{l}\text { Borehole } \\
\text { no. }\end{array}$ & Type & $\begin{array}{l}\text { Max CH4 productivity } \\
\text { during sampling }\end{array}$ & $\begin{array}{l}\text { No. of } \\
\text { samples }\end{array}$ \\
\hline Jleeb Al- & BH 4 & Native soil & $\mathrm{CH}_{4}<2 \%$ & 4 \\
\hline \multirow[t]{4}{*}{ Shuyoukh } & and 35 & $\begin{array}{l}\text { No buried } \\
\text { waste } \\
\text { underneath }\end{array}$ & Zero-productivity & \\
\hline & $\begin{array}{l}\text { BH } 21 \\
\text { and } 46\end{array}$ & $\begin{array}{l}\text { Waste buried } \\
\text { under } 1 \mathrm{~m}- \\
\text { soil layer }\end{array}$ & $\begin{array}{l}\mathrm{CH}_{4}=20-30 \% \\
\text { Low-productivity }\end{array}$ & 4 \\
\hline & $\begin{array}{l}\text { BH16 } \\
\text { and } 49\end{array}$ & $\begin{array}{l}\text { Waste buried } \\
\text { under } 1 \mathrm{~m}- \\
\text { soil layer }\end{array}$ & $\begin{array}{l}\mathrm{CH}_{4}=50-60 \% \\
\text { High-productivity }\end{array}$ & 4 \\
\hline & $\begin{array}{l}\text { BH 18 } \\
\text { Project } \\
\text { area "In } \\
\text {-situ aerobic } \\
\text { stabilization" }\end{array}$ & $\begin{array}{l}\text { Waste buried } \\
\text { under } \\
1 \mathrm{~m} \text {-soil layer }\end{array}$ & $\begin{array}{l}\mathrm{CH}_{4}=<3.3 \% \\
\text { After aeration }\end{array}$ & 8 \\
\hline \multirow[t]{2}{*}{ Al-Qurain } & $\begin{array}{l}\text { BH S17 } \\
\text { Under } \\
\text { 1m-soil layer } \\
\text { (LFG collection) }\end{array}$ & $\begin{array}{l}\text { Waste buried } \\
\text { Low-productivity }\end{array}$ & $\mathrm{CH}_{4}=20-30 \%$ & 4 \\
\hline & BH S12 & $\begin{array}{l}\text { Waste buried } \\
\text { under } 1 \mathrm{~m}- \\
\text { soil layer } \\
\text { (LFG collection) }\end{array}$ & $\begin{array}{l}\mathrm{CH}_{4}=50-60 \% \\
\text { High-productivity }\end{array}$ & 4 \\
\hline
\end{tabular}

\begin{tabular}{llllll}
\multicolumn{7}{l}{ Table 2: VOCs identified and quantified in LFG samples } \\
\hline 1 & Ethylene & 18 & N-Hexane & 35 & M/P Xylene \\
\hline 2 & Propane & 19 & MethylCyclopentane & 36 & Styrene \\
3 & Propylene & 20 & 2,4 DimethylPentane & 37 & O-Xylene \\
4 & Iso-Butane & 21 & Benzene & 38 & N-Nonane \\
5 & N-Butane & 22 & CycloHexane & 39 & IsoPropylBenzene \\
6 & Acetylene & 23 & 2-MethylHexane & 40 & N-PropylBenzene \\
7 & 1-Butene & 24 & 2,3DimethylPentane & 41 & M-EthylToluene \\
8 & Trans-2Butene & 25 & 3-MethylHexane & 42 & P-EthylToluene \\
9 & N-Pentane & 26 & 2,2,4TrimethylPentane & 43 & 1,3,5TriMethylBenzene \\
10 & Trans-2Pentane & 27 & N-Heptane & 44 & O-EthylToluene \\
11 & 1-Pentene & 28 & MethylCycloHexane & 45 & 1,2,4TriMethylBenzene \\
12 & Cis-2Pentene & 29 & 2,3,4TriMethylPentane & 46 & N-Decane \\
13 & 2,2 DiMethylButane & 30 & Toluene & 47 & $1,2,3$ TriMethylBenzene \\
14 & 2,3 DimethylButane & 31 & 2-MethylHeptane & 48 & M-DiethylBenzene \\
15 & 2 MethylPentane & 32 & 3-MethylHeptane & 49 & P-DiethylBenzene \\
16 & Isoprene & 33 & N-Octane & 50 & N-Undecane \\
17 & 1-Hexene & 34 & EthylBenzene & & \\
\hline
\end{tabular}

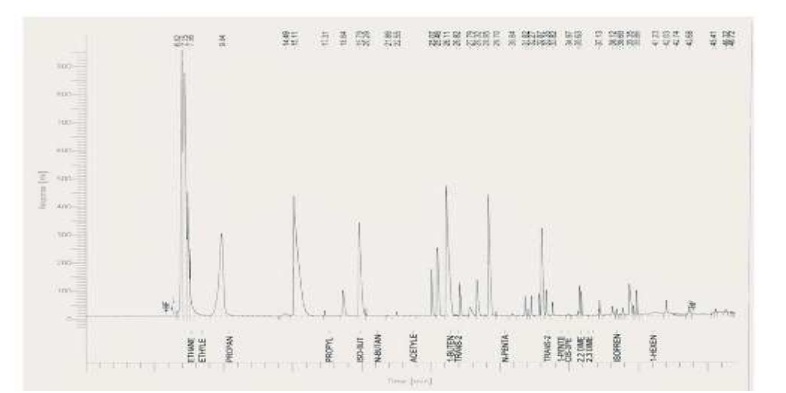

Fig. 4: GC/FID chromatogram of light VOCs identified in LFG samples

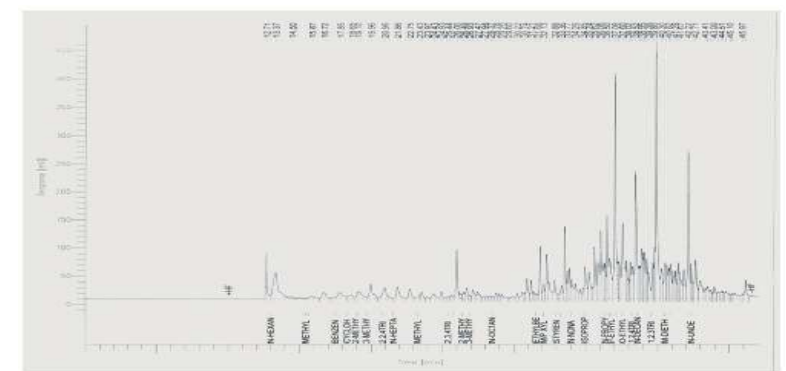

Fig. 5: GC/FID chromatogram of heavy VOCs identified in LFG samples

\section{RESULTS AND DISCUSSION}

Composition and concentrations of VOCs in LFG: Figure 6 and 7 compare the average concentrations of individual VOCs (50 compounds) measured in LFG samples collected from the different boreholes in the two landfill sites. It is evident from Fig. 7 and 8 that the composition of VOCs and the magnitude of measured concentrations are very much comparable between the high-productivity wells in the two landfill sites in AlJleeb and Al-Qurain where the correlation factor is relatively high $\left(R^{2}=0.7966\right)$. The highest concentrations of VOCs in all sampling sites were observed for; styrene, $m$-methyltoluene and diethylatedbenzenes.

Table 3 summarizes the results of total VOCs concentrations (sum of 50 compounds) measured in LFG emissions from the monitoring wells in Jleeb Al-Shuyoukh and Al-Qurain landfill sites. Concentrations of total VOCs ranged from as low as $1.3 \pm 0.5 \mathrm{ppm}$ in wells located in native soil areas up to $57.1 \pm 6.9 \mathrm{ppm}$ and $49.8 \pm 11.2$ in wells of highproductivity areas in both of Jleeb Al-Shuyoukh and Al-Qurain landfill sites, respectively.

The result show that the total VOCs emission from the project area (i.e., borehole No 18) is about one-half of the emission from the low-productivity wells in Jleeb landfill and about one-tenth of total VOCs emission from high-productivity wells. This significant reduction in VOCs emissions from the project area can be attributed to the high and rapid biological aerobic reactivity taking place in the project area. If this significant difference is converted into percent reduction in total VOCs emission relative to the emission from the high-productivity wells, then the insitu aerobic stabilization can speed up the decomposition of the biodegradable organic wastes and significantly reduce VOCs emissions by about $89 \%$ in comparison with the slow anaerobic biological reactions which usually needs several tens of years to decompose the buried wastes.

The distribution of major aromatic VOCs in LFG emissions: Table 4 represents a statistical summary of major aromatic VOCs concentrations measured in this study (i.e., benzene; toluene; ethylbenzene; $m-, p$ - and $o$-xylenes and styrene). Benzene concentrations ranged from as low as 5 ppb in LFG emissions from lowproductivity wells and up to $252.1 \mathrm{ppb}$ in LFG emissions from high-productivity wells. Xylene isomers (metha, para and ortho) and styrene were present in LFG emissions at much higher concentrations than benzene, toluene and ethylbenzene. The concentration of styrene reached as high as 4718.0 and $4057.8 \mathrm{ppb}$ in high-productivity wells in Jleeb AlShuyoukh landfill and Al-Qurain landfill, respectively. Schrapp and Al-Mutairi (2010) reported the concentrations 
Am. J. Environ. Sci., 8 (1): 56-63, 2012

of 13 VOCs including BTEX and styrene in LFG emissions from Jleeb Al-Shuyoukh landfill. Table 4 compares the results of BTEX and styrene measurements obtained in this study with those reported in the literature (Schrapp and Al-Mutairi, 2010; Al-Mutairi, 2004; Kim et al., 2006).

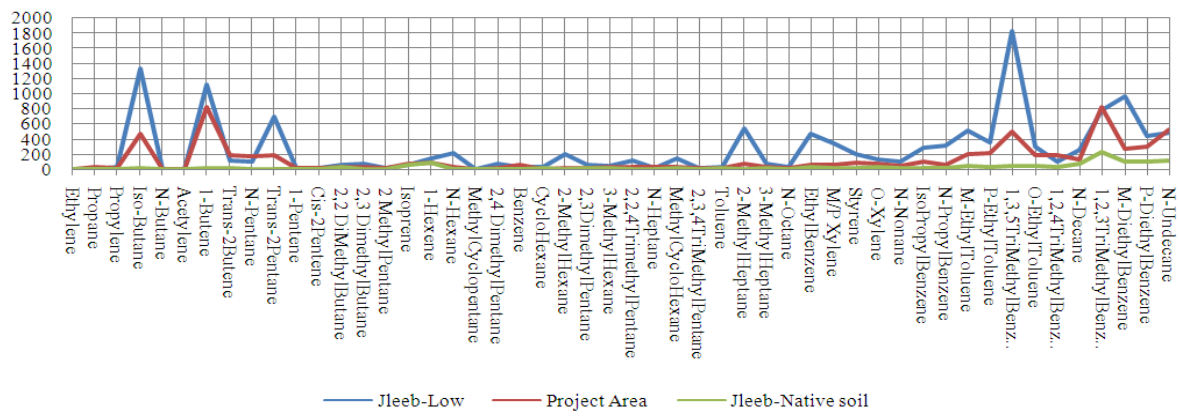

Fig. 6: Comparison of VOCs concentrations between low-productivity wells, native soil wells and the Project Area wells in Jleeb Al-Shuyoukh landfill (units are in ppb)

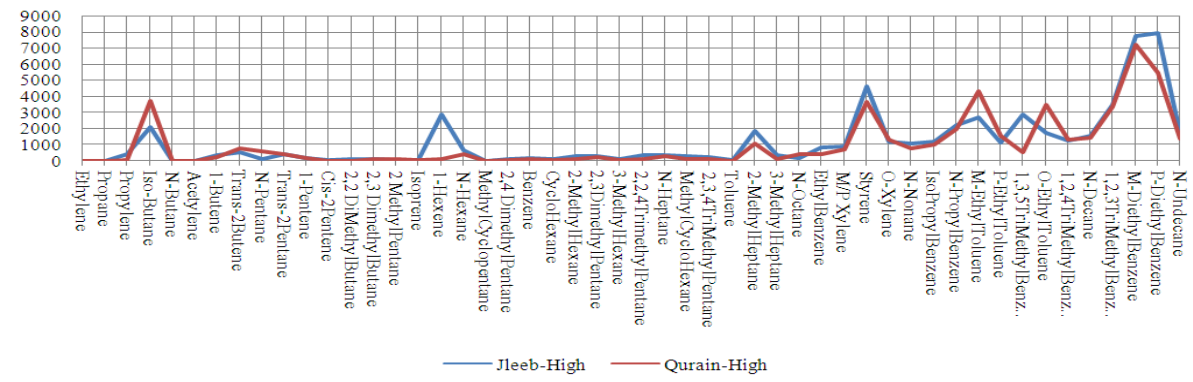

Fig. 7: Comparison of VOCs concentrations between Jleeb Al-Shuyoukh and Al-Qurain high-productivity wells (units are in $\mathrm{ppb}$ )

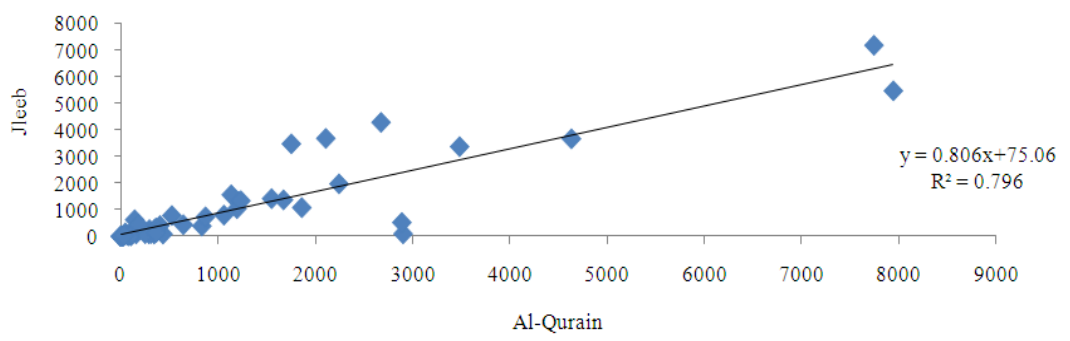

Fig. 8: Correlation of VOCs concentrations between Jleeb Al-Shuyoukh and Al-Qurain high-productivity wells (units in ppb)

Table 3: A statistical summary of VOCs concentrations measured in LFG emissions

\begin{tabular}{|c|c|c|c|c|}
\hline \multirow[b]{2}{*}{ Landfill Site } & \multirow[b]{2}{*}{ Borehole No. } & \multirow[b]{2}{*}{ Productivity } & \multicolumn{2}{|c|}{ Total $^{*}$ VOCs concentration (ppm) } \\
\hline & & & Mean \pm STD & Range (Min-Max) \\
\hline \multirow{6}{*}{$\begin{array}{l}\text { Jleeb } \\
\text { Al-Shuyoukh }\end{array}$} & BH 4 and 35 & $\mathrm{CH}_{4}<2 \%$ & $1.3 \pm 0.5$ & $(0.78-1.7)$ \\
\hline & & Zero-productivity & & \\
\hline & BH 21 and 40 & $\begin{array}{l}\mathrm{CH}_{4}=20-30 \% \\
\text { low-productivity }\end{array}$ & $13.1 \pm 2.9$ & $(9.4-15.7)$ \\
\hline & BH16 and 49 & $\begin{array}{l}\mathrm{CH}_{4}=50-60 \% \\
\text { high-productivity }\end{array}$ & $57.1 \pm 6.9$ & $(51.9-67.2)$ \\
\hline & BH 18, project area & $\mathrm{CH}_{4}=<3.3 \%$ & $6.3 \pm 1.6$ & $(4.7-9.1)$ \\
\hline & "In-situ aerobic & after aeration & & \\
\hline \multirow{2}{*}{ Al-Qurain } & stabilization"BH S17 & $\begin{array}{l}\mathrm{CH}_{4}=20-30 \% \\
\text { low-productivity }\end{array}$ & & \\
\hline & BH S12 & $\mathrm{CH}_{4}=50-60 \%$ high-productivity & $49.8 \pm 11.2$ & $(41.2-57.7)$ \\
\hline
\end{tabular}

*; Sum of 50 VOCs 
Am. J. Environ. Sci., 8 (1): 56-63, 2012

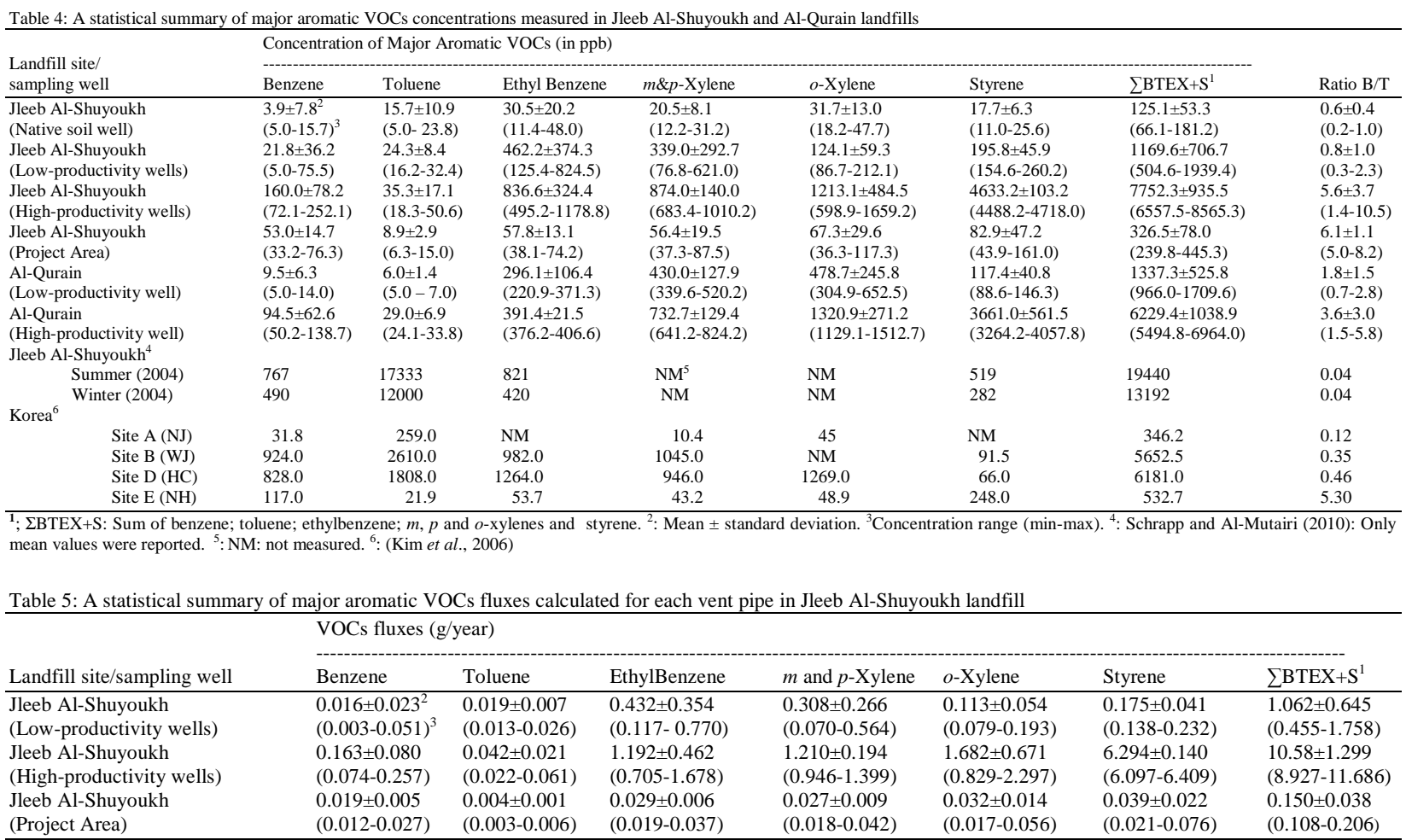

${ }^{1} \Sigma \mathrm{BTEX}+\mathrm{S}$ : Sum of benzene; toluene; ethylbenzene; $m, p, o$-xylenes and styrene. ${ }^{2} \mathrm{Mean} \pm$ standard deviation. ${ }^{3}$ Concentration range (min- max)

As shown in Table 4 and Fig. 9 that the sum of BTEX and styrene emissions $(\Sigma B T E X+S)$ was comparable between Jleeb Al-Shuyoukh high-productivity wells (7752.3 ppb) and Al-Qurain high-productivity wells (6229.4 ppb) and also with those reported for sites B and D in Korea, 5652.5 $\mathrm{ppb}$ and $6181 \mathrm{ppb}$, respectively.

$\mathrm{BTEX}+\mathrm{S}$ emission from high-productivity wells in Jleeb Al-Shuyoukh are almost half of those calculated for BTEX and styrene measured in 2004 (Schrapp and Al-Mutairi, 2010). $\Sigma$ BTEX+S emission from Jleeb Al-Shuyoukh low-productivity wells (1169.6 ppb) was also comparable with $\Sigma \mathrm{BTEX}+\mathrm{S}$ emission from Al-Qurain low-productivity wells (1337.3 ppb). Interestingly, the average emission of $\Sigma \mathrm{BTEX}+\mathrm{S}$ from monitoring wells in the project area was significantly reduced down to $326.5 \mathrm{ppb}$ which is only $200 \mathrm{ppb}$ higher than the measured $\Sigma \mathrm{BTEX}+\mathrm{S}$ emissions from the native soil boreholes in the background of Jleeb Al-Shuyoukh landfill site.

The Benzene-to-Toluene ratio $(\mathrm{B} / \mathrm{T})$ is widely used in source apportionment studies to evaluate VOC emission characteristics from different sources. It has been reported that the $\mathrm{B} / \mathrm{T}$ ratio was between 0.015 and 0.11 for landfill gas, 0.5 for vehicle exhaust gas and between 0.27 and 0.5 for typical urban atmospheric environment (Dincer et al., 2006). Other studies have also reported $\mathrm{B} / \mathrm{T}$ ratios between 0.01 and 0.2 for landfill gas (Kim et al., 2006). Kim et al. (2006) measured
VOCs emissions from five landfill sites in Korea and reported that $\mathrm{B} / \mathrm{T}$ ratios varied significantly between 0.12 and 5.3. Urase et al. (2008) reported B/T ratio as high as 8 at a location in a landfill site in Tokyo-Japan.

As shown in Table 4, in the present study we observed low $\mathrm{B} / \mathrm{T}$ ratios in the native soil wells and also in low-productivity wells in Jleeb Al-Shuyoukh landfill site of 0.6 and 0.8 , respectively; whereas, higher $\mathrm{B} / \mathrm{T}$ ratios of 6.1 and 5.6 were observed in the project area "In-situ aerobic stabilization" and in high-productivity wells in Jleeb Al-Shuyoukh and AlQurain landfill, respectively. These high $\mathrm{B} / \mathrm{T}$ ratios in the project area and in the high-productivity wells can be attributed to the higher biological reactivity and reactions taking place in the vicinity of these. The temperature inside the waste layer is known to go up to $80^{\circ} \mathrm{C}$ occasionally. The exposure of the plastics in solid waste layer to such high temperature is probably one of the reasons for the release of VOCs from solid waste disposal sites. Figure 10 also shows that there was a good correlation $\left(\mathrm{R}^{2}=0.9242\right)$ between $\mathrm{B} / \mathrm{T}$ ratios and $\Sigma \mathrm{BTEX}+\mathrm{S}$ emissions for Jleeb Al-Shuyoukh and AlQurain high-productivity wells which further demonstrates the similarity in the chemical and biological processes, types and age of buried wastes as well as other local conditions between the two landfills leading to similar composition and concentrations of VOCs in LFG emissions. 
Am. J. Environ. Sci., 8 (1): 56-63, 2012

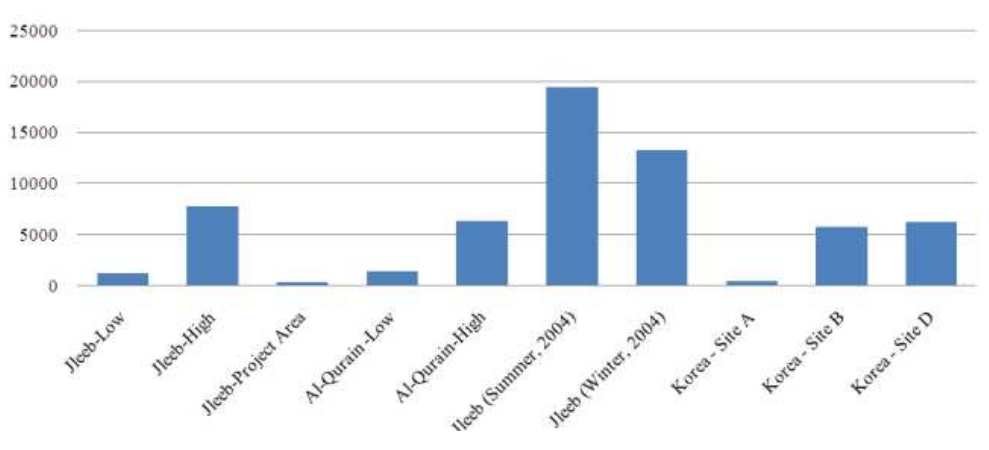

Fig. 9: Comparison of $\Sigma B T E X+$ Styrene measured in this study with those reported in the literature (in ppb)

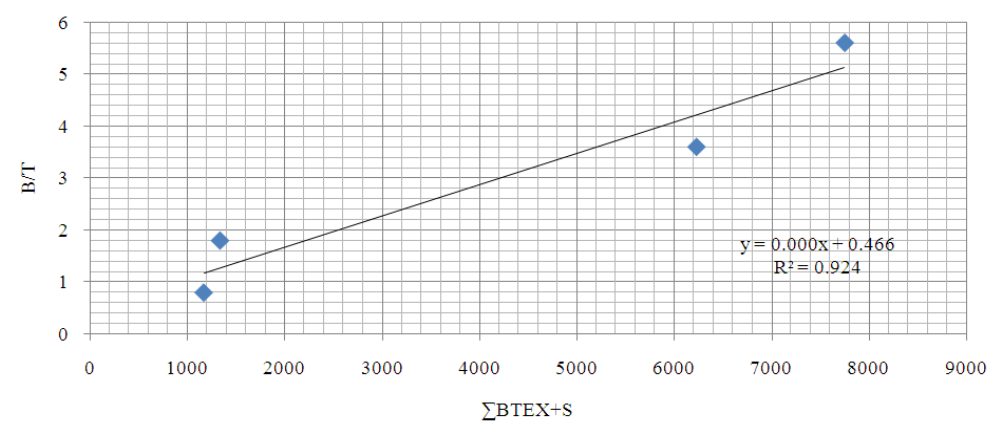

Fig. 10: Correlation between $\mathrm{B} / \mathrm{T}$ and $\Sigma \mathrm{BTEX}+\mathrm{S}$ in Jleeb Al-Shuyoukh and Al-Qurain

Estimation of VOCs annual emission rates: One of the objectives of the present study includes accurate identification and quantification of VOCs emissions from the two major landfill sites in Kuwait (i.e., Jleeb Al-Shuyoukh and Al-Qurain). The availability of this kind of information can help in evaluating the emission potential of a given landfill environment. For this purpose, the major five VOCs (i.e., benzene; toluene; ethylbenzene; m-, p- and o-xylenes and styrene) were computed for each sampled monitoring well in Jleeb Al-Shuyoukh landfill using their concentrations and the concurrently determined flow rates of LFG.

However, as our estimation is based on a relatively limited quantity of data sets such results may only be used at this stage as rough estimates for the extent of VOC emissions from landfill sites in Kuwait. Table 5 lists the results calculated in terms of the average $\Sigma$ BTEX+S quantity emitted per vent pipe per year which showed that the magnitude of their annual emission rates can vary substantially, with the values ranging between 0.108-11.686 $\mathrm{g} \mathrm{y}^{-1}$.

\section{CONCLUSION}

During this study it was possible for the first time in Kuwait to identify and quantify 50 Volatile Organic
Compounds (VOCs) in LFG emissions from two old landfill sites in Kuwait. The compounds identified included the well-known four aromatic VOCs; Benzene, Toluene, Ethylbenzene and $o-, m$ and $p$ Xylenes (BTEX). Styrene was also identified and its concentration level was the highest amongst aromatic VOCs. Concentrations of total VOCs (i.e., sum of 50 compounds) in LFG emissions varied between 9.4-67.2 ppm in Jleeb Al-Shuyoukh landfill site and from 15.4$57.7 \mathrm{ppm}$ in Al-Qurain landfill site.

The results obtained in this study demonstrated that the concentration levels of VOCs were found to be significantly different within the same landfill site depending on the reactivity and productivity of the biological decomposition processes of buried wastes. In addition, the results also demonstrated that total VOCs emissions were comparable between the two landfill sites.

This study demonstrated that the "in-situ aerobic stabilization method" applied in the project area of Jleeb Al-Shuyoukh landfill for the treatment of old waste deposits in landfills can significantly reduce the emission of VOCs in LFG by as much as $89 \%$.

\section{ACKNOWLEDGMENT}

This study was supported by the Universty of Rostock in Germany as part of $\mathrm{PhD}$ research at the 
Department of Waste Management/Institute of Environmental Engineering. The authors thank the Environment Public Authority in Kuwait for the analysis of leachates and groundwater samples in their laboratories. Thanks are due to the "Landfill Rehabilitation Committee" in Kuwait (the TripleCommittee) for their suport of this work. Thanks are also due to Mr. Ismail Abdulghani and Mr. Faysal Rageb for thier technical assitsnace and to Mr. Jasim Al-Hasawi for his administrative assistance.

\section{REFERENCES}

Abushammala, M.F., N. Basri and E.A. Khadum, 2009. Review on Landfill gas emission to the atmosphere. European J. Sci. Res., 30: 427-436.

AlAhmad, M., 2009. In-Situ Aerobic Stabilization of Solid Wastes in Jleeb Al-Shuyoukh Landfill. Unpublished data

AlAhmad, M., F. Mahrous and M. Mouawad, 2003. Current Status and Strategy for the Rehabilitation of Closed Landfills in Kuwait. 1st Edn., Environment Public Authority, Kuwait.

Al-Mutairi, N., 2004. Biological, Chemical and Physical Assessment of Jeleeb Al-shuyoukh Landfill. Kuwait Environment Public Authority, State of Kuwait.

Awomeso, J.A., A.M. Taiwo, A.M. Gbadebo and A.O. Arimoro, 2010. Waste disposal and pollution management in urban areas: A workable remedy for the environment in developing countries. Am. J. Environ. Sci., 6: 26-32. DOI: 10.3844/ajessp.2010.26.32

Cossu, R., S. Cestaro and D. Rossetti, 2006. Full-Scale application of aerobic in-situ stabilization of an old landfill in north Italy. Proceedings of the 4th Intercontinental Landfill Research Symposium, (ICLRS' 06), Gallivare, Sweden.

Dincer, F., M. Odabasi and A. Muezzinoglu, 2006. Chemical characterization of odorous gases at a landfill site by gas chromatography-mass spectrometry. J. Chromatography A, 1122: 222229. DOI: 10.1016/j.chroma.2006.04.075

Heyer, K.U., K. Hupe, A. Koop and R. Stegmann, 2005. Aerobic in situ stabilization of landfills in the closure and aftercare period. Proceedings of the 10th International Waste Management and Landfill Symposium, Oct. 3-7, Sardinia, Italy.

Heyer, K.U., K. Hupe, A. Koop, M. Ritzkowski and R. Stegmann, 2003. The low pressure aeration of landfills: Experience, operation and costs. Proceedings of the 9th International Waste Management and Landfill Symposium, Oct. 6-10, Sardinia, Italy.
IPCC, 2006. IPCC Guidelines for national greenhouse gas inventories. Intergovernmental Panel on Climate Change.

Kim, K.H., O.K. Baek, Y.J. Choi, Y. Sunwoo and E.C. Jeon et al., 2006. The Emissions of major aromatic VOC as Landfill gas from urban landfill sites in Korea. Environ. Monitor. Ass., 118: 407-422. PMID: 16897554

Parker, T., J. Dottridge and S. Kelly, 2002. Investigation of the composition and emissions of trace components in landfill gas. Environment Agency, Bristol.

Schrapp, K. and N. Al-Mutairi, 2010. Associated health effects among residences near Jleeb Al-Shuyoukh Landfill. Am. J. Environ. Sci., 6: 184-190. DOI: 10.3844/ajessp.2010.184.190

Spillmann, P., T. Dorrie, A. Nassour and M. Struve, 2001. Re-use landfill areas through specific treatment. Proceedings of the 4th Middle East Conference on the Role of Environmental Awareness in Waste Management, Nov. 10-12, Environment Protection Society, State of Kuwait, pp: 127-133.

Stern, J.C., J. Chanton, T. Abichou, D. Powelson and L. Yuan et al., 2007. Use of a biologically active cover to reduce landfill methane emissions and enhance methane oxidation. Waste Manage., 27: 1248-1258. 10.1016/j.wasman.2006.07.018

UNDP, 2002. Kuwait environmental strategy-part 1. United Nations Development Programme.

Urase, T., H. Okumura, S. Panyosaranya and A. Inamura, 2008. Emission of volatile organic compounds from solid waste disposal sites and importance of heat management. Waste Manage. Res., 26: 534-538. DOI: 10.1177/0734242X07084321

Wang-Yao, K., S. Towprayoon, C. Chiemchaisri, S.H. Gheewala and A. Nopharatana, 2006. Seasonal variation of landfill methane emissions from seven solid waste disposal sites in central Thailand. Proceedings of 2nd Joint International Conference on Sustainable Energy and Environment, Nov. 21-23, Bangkok, Thailand, pp: 1-4.

Williams, P.T., 2005. Waste Treatment and Disposal. 2nd Edn., John Wiley Sons, Chichester, ISBN-10: 0470849126, pp: 380.

Zanetti, M.C., 2008. Aerobic biostabilization of old MSW landfills. Am. J. Eng. Applied Sci., 1: 393398. DOI: 10.3844/ajeassp.2008.393.398 